\title{
Fluorometric quantification of protoporphyrin IX in biological skin samples from in vitro penetration/permeation studies
}

\author{
Fábia Cristina Rossetti ${ }^{1}$, Lívia Vieira Depieri ${ }^{1}$, Antônio Cláudio Tedesco ${ }^{2}$, \\ Maria Vitória Lopes Badra Bentley ${ }^{1 *}$
}

\begin{abstract}
${ }^{1}$ Department of Pharmaceutical Sciences, Faculty of Pharmaceutical Sciences of Ribeirão Preto, University of São Paulo, ${ }^{2}$ Department of Chemistry, Faculty of Philosophy, Sciences and Letters of Ribeirão Preto, University of São Paulo
\end{abstract}

\begin{abstract}
A fluorometric analytical method was developed for quantification of protoporphyrin IX (PpIX) in skin samples and receptor phase solution after in vitro cutaneous penetration/permeation studies. Analytical conditions used were: excitation and emission wavelengths: $400 \mathrm{~nm}$ and $632 \mathrm{~nm}$; bandwidth: $0.5 \mathrm{~nm}$; excitation and emission slits: 10/10. PpIX was recovered from two different layers of skin, the stratum corneum (SC) and the epidermis plus dermis ([E+D]), by vortex homogenization, probe and bath sonication, using DMSO as an extraction solvent. The detection and quantification limits were 0.002 and $0.005 \mu \mathrm{g} / \mathrm{mL}$, respectively. The assay was linear from $0.005-0.5 \mu \mathrm{g} / \mathrm{mL}$. The within-day and betweenday assay precision and accuracy in DMSO and receptor phase solution were each studied at the two concentration levels 0.04 and $0.2 \mu \mathrm{g} / \mathrm{mL}$, and 0.01 and $0.08 \mu \mathrm{g} / \mathrm{mL}$, respectively. The coefficients of variation and deviation from the theoretical values were lower than 5\%. The skin recovery of PpIX from $\mathrm{SC}$ and $[\mathrm{E}+\mathrm{D}]$ layers using two different concentrations $(0.5$ and $1.0 \mu \mathrm{g} / \mathrm{mL})$ were all above $90.0 \%$. The method described has potential application to in vitro penetration/permeation studies of PpIX using porcine skin as a biological membrane model.
\end{abstract}

Uniterms: Fluorometric quantification. Protoporphyrin IX/determination. Photodynamic therapy. Porcine skin. Cutaneous penetration/in vitro study. Cutaneous permeation/in vitro study.

Um método analítico por espectrofluorimetria foi desenvolvido para quantificar a protoporfirina IX (Pp IX) em amostras de pele e fase receptora após a realização de testes in vitro de penetração/permeação cutâneas. As condições analíticas utilizadas foram: comprimentos de onda de excitação e emissão: $400 \mathrm{~nm}$ e $632 \mathrm{~nm}$; largura de banda: 0,5 nm; fendas de excitação e emissão: 10/10. A PpIX foi extraída de amostras de estrato córneo (EC) e da epiderme sem estrato córneo + derme ([E+D]) através da agitação em vórtex e sonicação por haste e banho, utilizando-se o DMSO como solvente extrator. O limite de detecção e quantificação foram, respectivamente, de 0,002 e $0,005 \mu \mathrm{g} / \mathrm{mL}$. O método mostrou-se linear da faixa de $0,005-0,5 \mu \mathrm{g} / \mathrm{mL}$. A precisão e exatidão intra e inter-ensaio em DMSO e na fase receptora foram validadas utilizando-se duas concentrações distintas, respectivamente, de 0,004 e $0,2 \mu \mathrm{g} / \mathrm{mL}$, e 0,01 e $0,08 \mu \mathrm{g} / \mathrm{mL}$. Os valores de coeficiente de variação e o desvio do valor teórico foram inferiores a 5\%. A recuperação da PpIX das camadas da pele $(\mathrm{EC}$ e $[\mathrm{E}+\mathrm{D}])$ utilizando-se duas concentrações distintas $(0,5$ e $1,0 \mu \mathrm{g} / \mathrm{mL})$ foram todas acima de $90,0 \%$. O método descrito pode ser utilizado para determinação da PpIX após estudos de penetração/permeação cutânea in vitro utilizando pele de porco como modelo de membrana.

Unitermos: Espectrofluorimetria/análise quantitativa. Quantificação fluorimétrica. Protoporfirina IX/ determinação. Terapia fotodinâmica. Pele porcina. Penetração cutânea/estudo in vitro. Permeação cutânea/estudo in vitro.

\footnotetext{
*Correspondence: M. V. L. B. Bentley. Departamento de Ciências Farmacêuticas, Faculdade de Ciências Farmacêuticas de Ribeirão Preto, Universidade de São Paulo. Av do Café, s/n - 14040-903 - Ribeirão Preto - SP, Brasil. E-mail: vbentley@usp.br
} 


\section{INTRODUCTION}

Fluorescence spectroscopy has gained increasing importance in recent years, especially in molecular and cellular biology, and in many associated areas of biochemical analysis, because it offers many advantages such as extreme sensitivity, a high degree of selectivity, and exceptional flexibility in measuring a range of solid and liquid sample formats (Miller, 2006).

Fluorescence detection of a molecule capable of emitting fluorescence efficiently, called a photosensitizer (PS), is an analytical and sensitive method used to quantify the amount of PS in cells or tissues, and allows in vivo fluorescence imaging in living animals or patients to measure the pharmacokinetics and distribution of the PS (Castano, Demidova, Hamblin, 2004). Moreover, PSs are currently been used to treat different types of cancer, including non-melanoma skin cancers in a therapy called photodynamic therapy, that produces highly reactive lethal substances for tumorous cells through the combination of light, PS and oxygen (Brown, Brown, Walker, 2004; Zeitouni, Oseroff, Shieff, 2003).

The study of the use of protoporphyrin IX (PpIX), an endogenous porphyrin, as a PS is promising because it has fast degradation in normal tissue compared to abnormal tissue, which leads to a short period of sensitization thereby reducing the collateral effects of the photodynamic therapy (Kennedy, Pottier, Pross, 1990). In addition, its topical administration in the treatment of non-melanoma skin cancer in comparison to systemic application can be more efficient, since higher local concentrations in the cancerous tissue can be obtained (Rick et al., 1997).

Because the skin penetration and permeation of most PSs remains unknown, it is crucial to quantify accurately and precisely the skin uptake and transdermal delivery of these compounds in the development of topical formulations. The main method to study the drug release performance into/through the skin is the in vitro test performed in a Franz Diffusion Cell using pig's ear skin as a biological model for skin (Schmook, Meingassner, Billich, 2001).

The physicochemical characteristics of the PpIX allows the development of an analytical method for its quantification based on fluorescence spectroscopy, since this PS is able to emit fluorescence after excitation by a beam of light with an adequate wavelength (Castano, Deminova, Hamblin, 2004; De Rosa et al., 2000).

The aim of the present study was to contribute to the area of topical drugs development, through the development of an accurate and precise method to quantify PpIX in skin samples from cutaneous penetration/permeation in vitro tests. To this end, a fluorometric analytical method was validated.

\section{MATERIAL AND METHODS}

\section{Standard solutions and chemicals}

A standard solution of PpIX $(50 \mu \mathrm{g} / \mathrm{mL})$ in dimethylsulfoxide (DMSO) was prepared and stored in the dark at $-5{ }^{\circ} \mathrm{C}$ for 15 days. Working solutions ( 0.005 to $2.0 \mu \mathrm{g} / \mathrm{mL}$ ) were prepared by appropriate dilutions with DMSO and phosphate buffer (100 mM, pH 7.2) - containing cetylpyridinium chloride (CPC) at $30 \mathrm{mM}$ - and were freshly used. DMSO of analytical grade was purchased from Merck (Germany).

\section{Equipment and spectrofluorometric conditions}

Fluorometric quantification and validation were performed using a Hitachi - F-4500 (Tokyo, Japan) spectrofluorometer ( $\lambda$ excitation: $400 \mathrm{~nm}$; $\lambda$ emission: $632 \mathrm{~nm}$; bandwidth: $0.5 \mathrm{~nm}$; excitation and emission slit: 10/10).

\section{Skin preparations}

The penetration of PpIX in the skin was assessed using an in vitro model of porcine ear skin, as previously described (Lopez et al., 2001). Briefly, the skin from the outer surface of a freshly excised porcine ear was carefully dissected (making sure that the subcutaneous fat was maximally removed), stored at $-20{ }^{\circ} \mathrm{C}$, and used within a month.

\section{PpIX recovery from porcine skin samples}

The absolute recovery of PpIX from skin tissue was determined for two concentrations $(0.5$ and $1.0 \mu \mathrm{g} / \mathrm{mL})$. This was performed by spiking samples of adhesive tape (14 pieces) containing stratum corneum (SC), subjected to tape stripping, and the remaining skin sections $\left(0.78 \mathrm{~cm}^{2}\right)$, referring to epidermis (E) plus dermis (D) tissue, with a PpIX solution in DMSO $(10.0 \mu \mathrm{g} / \mathrm{mL})$. The spiked skin samples $(\mathrm{n}=5), \mathrm{SC}$ and $[\mathrm{E}+\mathrm{D}]$, were allowed to rest for 60 minutes before PpIX extraction. The PpIX extraction from the adhesive tapes containing the $\mathrm{SC}$ and [E+D] was done as follows: each skin sample was immersed in $4 \mathrm{~mL}$ of DMSO; the system was vortex stirred for $2 \mathrm{~min}$; bath sonicated ( $40 \mathrm{KHz}$, continuous mode) for 30 minutes and the resulting mixture was then filtrated using 0.45 $\mu \mathrm{m}$ membranes, and PpIX determined in the filtrate by spectrofluorometric assay. The $[E+D]$ samples were cut 
into small pieces before being immersed in DMSO and submitted to probe sonication $(22.5 \mathrm{kHz})$ for 30 seconds after vortex stirring and before bath sonication.

\section{PpIX solubility and aggregation behavior in Phosphate Buffer (100 mM, pH 7.2)}

The receptor phase developed for the in vitro penetration studies was a phosphate buffer $(100 \mathrm{mM}$, $\mathrm{pH}$ 7.2) containing the cationic surfactant $\mathrm{CPC}$ at $30 \mathrm{mM}$ (concentration above surfactant critical micelle concentration- CMC). PpIX solubility and monomerization in the receptor phase were checked for possible PpIX quantification.

The solubility of PpIX was determined $(n=3)$ by adding an excess amount of PpIX in $5 \mathrm{~mL}$ of the receptor phase and leaving this overnight under constant stirring. Subsequently, the samples were centrifuged at $704.0 \mathrm{~g}$ for 10 minutes and filtrated using $0.45 \mu \mathrm{m}$ membranes, and PpIX was determined spectrophotometrically in the filtrate by using a UV-vis FEMTO 800 XI. To verify the aggregation behavior of PpIX in the receptor phase, the absorption spectrum from a $2.0 \mu \mathrm{g} / \mathrm{mL}$ PpIX receptor phase solution was compared to the spectrum in the same PpIX concentration in a monomeric solution (DMSO).

\section{In vitro skin penetration/permeation}

The assay developed for PpIX quantification in porcine skin was used to determine PpIX skin penetration after in vitro cutaneous penetration experiments. On the day of the experiment, the cleaned porcine ear skin was mounted in a Franz diffusion cell (diffusion area of $0.78 \mathrm{~cm}^{2}$; Hanson Research, Chatsworth, CA, USA), with the $\mathrm{SC}$ facing the donor compartment and the dermis facing the receptor compartment, which was filled with the receptor phase of $100 \mathrm{mM}$ phosphate buffer $(\mathrm{pH}$ 7.2) containing CPC at $30 \mathrm{mM}$ for PpIX solubilization.

The system was maintained at $37^{\circ} \mathrm{C}$ and under constant stirring. Five hundred milligrams of a solution composed of PpIX at $80 \mu \mathrm{g} / \mathrm{mL}(\mathrm{w} / \mathrm{w})$ in polyethylene glycol (PEG) $(n=5)$ was applied to the surface of the SC (in the donor compartment), and the concentration of PpIX in the $\mathrm{SC}$ and $[\mathrm{E}+\mathrm{D}]$ was determined at $12 \mathrm{~h}$ post-application. At the end of the experiment, skin surfaces were thoroughly washed with distilled water to remove excess formulation. PpIX was extracted from SC and [E+D] using the methodology described above (in the item PpIX recovery from porcine skin). The amount of drug detected in $\mathrm{SC}$ and in $[\mathrm{E}+\mathrm{D}]$ was indicative of drug penetration into the skin. The amount of drug detected in the receptor phase (phosphate buffer $\mathrm{pH} 7.2+\mathrm{CPC}$ ) was indicative of drug permeation through the skin.

The samples from the $\mathrm{SC},[\mathrm{E}+\mathrm{D}]$ and permeation (receptor phase) protected from light were stable for 24 hours at room temperature after the $12 \mathrm{~h}$ in vitro penetration/permeation experiment.

\section{PpIX assay specifications}

The validation of a bioanalytical method is the process used to establish that analytical performance parameters are adequate for their intended use (Causon, 1997). Based on this, we evaluated several parameters to demonstrate that the analytical procedure was suitable for analyzing PpIX in skin and receptor phase samples from in vitro skin penetration studies.

Linearity responses were verified by using DMSO and receptor phase solutions of PpIX in concentrations ranging from 0.005 to $1.5 \mu \mathrm{g} / \mathrm{mL}$. The precision and accuracy of the method were tested on a within-day and between-day basis. For the determination of the withinday precision and accuracy, ten (10) PpIX DMSO and receptor phase solution replicate aliquots at concentrations of 0.04 and $0.2 \mu \mathrm{g} / \mathrm{mL}$ and 0.01 and $0.08 \mu \mathrm{g} / \mathrm{mL}$, respectively, were analyzed. The between-day precision and accuracy were determined by analyzing 5 aliquots of the same PpIX solutions on five consecutive days. The range, defined as the interval between the high and low levels of the analyte studied, was obtained based on the linearity. The within-day precision and accuracy of the lower limit of quantification (LOQ) were determined by analyzing 7 aliquots of the same PpIX solutions.

The precision of the assay was calculated as the relative standard deviation (coefficient of variation, $\mathrm{CV}$ ), whereas the accuracy was calculated as the relative error of the mean, between expected and calculated concentrations, according to the following equation:

Accuracy $(\%)=($ calculated mean - theoretical $/$ theoretical) x 100 .

The requirements are met if $\mathrm{CV}$ for each concentration does not exceed 15\% (Causon, 1997; ANVISA resolution number 899), except for LOQ, for which larger values (up to 20\%) are allowed (ANVISA resolution number 899, Shah et al., 1992).

The sensitivity of the method was evaluated by determining the lower LOQ and the detection limit. The LOQ was set as the lowest PpIX concentration that could be determined with adequate precision and accuracy, whereas the lower limit was the lowest PpIX concentration that could be detected but not quantified under the stated experimental conditions (Causon, 1997; Santana et al., 2004). 
The detection and quantification limits were calculated by analyzing diluted solutions of PpIX in concentrations ranging from $0.001-0.005 \mu \mathrm{g} / \mathrm{mL}$.

The selectivity of the method was verified by evaluating the interference of skin compounds and of the adhesive tape on the assay of PpIX. Samples of control skin (treated with Milli Q water) were submitted to the same procedure to extract PpIX, as described in the item PpIX recovery from porcine skin. The homogenates of SC and $[\mathrm{E}+\mathrm{D}]$ were assayed spectrofluorometrically.

\section{Calibration curves}

Calibration curves to assay PpIX in skin samples were constructed by assaying DMSO solutions of the drug at concentrations ranging from 0.005 to $0.1 \mu \mathrm{g} / \mathrm{mL}$.

\section{RESULTS AND DISCUSSION}

PpIX is the immediate precursor of haem in the biosynthetic pathway for haem. It is an endogenous PS that is transiently intracellularly accumulated after an excess of exogenous 5-aminolevulinic acid (5-ALA) bypasses the negative feedback control mechanism of 5-ALA synthesis (Kennedy; Pottier; Pross, 1990). PpIX is the drug assayed in blood, biological matrices and tissues after 5-ALA administration. The main methods developed for its quantification are spectrofluorometry (Pierre et al., 2006; Steluti et al., 2005) and HPLC with fluorescence (Boddé, Roemelé, Star, 2002; De Rosa et al., 2003; Oishi et al., 1996) or ultraviolet detection (Mateo et al., 2004).

DMSO was chosen to extract PpIX from the skin in the in vitro penetration experiments due to its solvent properties and PpIX's good solubility in this medium. According to Scolaro et al. (2002), porphyrins exhibit aggregation, a $\pi$ - $\pi$ stacking interaction in water while spectroscopic studies performed in water as a function of $\mathrm{pH}$ demonstrated that they are monomer between $\mathrm{pH}$ 0-3; dimmer in $\mathrm{pH}$ above 8 and higher aggregates in the $\mathrm{pH}$ 3-7. At $\mathrm{pH} 1$, PpIX absorption spectra exhibits a strong absorption band (B-band) at $\lambda(\mathrm{nm})=406(1.7)$ and four weaker absorption bands (Q-bands) at $\lambda(\mathrm{nm})=516(9.6)$; 554 (17.2); 600 (11.6) and 626 (8.0). Similarly, in DMSO where PpIX is a monomer, the B-band is located at $\lambda(\mathrm{nm})$ $=408(1.7)$ and Q-bands are at $\lambda(\mathrm{nm})=506(16.4) ; 542$ (13.3); 577 (8.6); 630 (6.2). The emission spectra in water at $\mathrm{pH} 1$ exhibits two fluorescence bands at $\lambda(\mathrm{nm})=604$ and 660, and in DMSO at $\lambda(\mathrm{nm})=624$ and 684 .

In order to avoid strong acidic media that would promote PpIX monomer form in the receptor phase from the in vitro experiments, we chose to use a cationic surfactant
$\mathrm{CPC}$ at $30 \mathrm{mM}$ (concentration above its C.M.C.) to promote PpIX monomerization in this phase. PpIX solubility performed in this phase was $31.66 \pm 0.65 \mu \mathrm{g} / \mathrm{mL}$. PpIX is an anionic molecule and spectroscopic studies performed in aqueous media containing the cationic surfactant named hexadecyltrimethylammonium bromide demonstrated good PpIX solubilization due to electrostatic interactions, reflecting a strong absorption band (B-band) at $\lambda(\mathrm{nm})=$ 409 , and four weaker absorption bands (Q-bands) at $\lambda(\mathrm{nm})$ $=505 ; 540 ; 578 ; 632$; and strong fluorescence emission at $\lambda(\mathrm{nm})=633$ (Sivash; Masinovsk; Lozovaya, 1991).

The absorption spectrum (Figure 1) in DMSO and phosphate buffer containing CPC demonstrated a strong absorption band (B-band) at $\lambda(\mathrm{nm})=406$ and 408 and four weaker absorption bands (Q-bands) at $\lambda(\mathrm{nm})=506$; 540; 574 and 576 and 630 and 632, respectively. The emission spectrum (Figure 2) in the same media demonstrated strong fluorescence emission at $\lambda(\mathrm{nm})=632$ and 634 , respectively. Similar behavior to PpIX spectra were

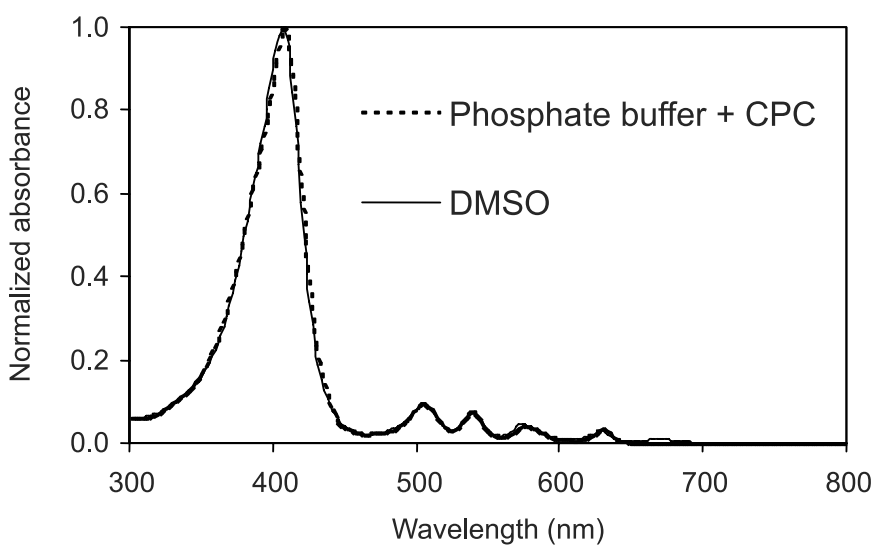

FIGURE 1 - Normalized absorption spectra of PpIX $(2.0 \mu \mathrm{g} / \mathrm{mL})$ in the solvents used for the in vitro penetration studies.

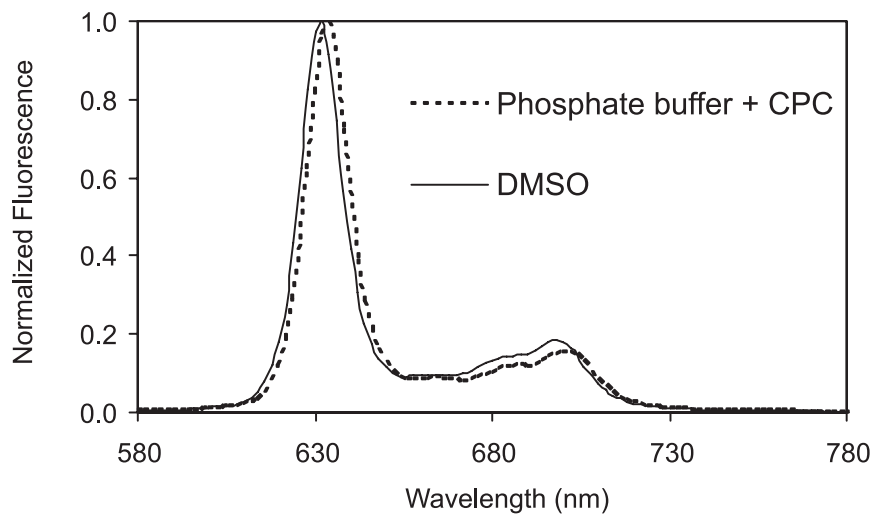

FIGURE 2 - Normalized fluorescence spectra of PpIX $(2.0 \mu \mathrm{g} / \mathrm{mL})$ in the solvents used for the in vitro penetration studies. Specifications: $\lambda$ excitation $(\mathrm{nm})=400 / \lambda_{\max }$ emission $(\mathrm{nm})=$ 632 and 634; excitation/emission Slits: $5.0 / 5.0 \mathrm{~nm}$. 
described in the previously cited studies, confirming PpIX monomer form in these solvents.

Fluorescence emission is a sensitive and reliable tool for measuring PpIX in ex vivo tissue (Pierre et al., 2006; Steluti et al., 2005). The selectivity of the method is related to the autofluorescence of the skin and adhesive tape compounds which can fluoresce in the same $\lambda$ of the PS. The main endogenous compounds (fluorophores) in pig skin, which determine the fluorescence signal of normal skin, are similar to those found in humans and the differences are related to the different content of a specific fluorophore in the animal cutaneous tissue and different percentage of an exact compound type - for example, collagen (Drakaki et al., 2007). The maximum $\lambda$ emission for PpIX determined in DMSO was around $630 \mathrm{~nm}$ when excited at $\lambda=400 \mathrm{~nm}$ (Figure 3). However, the fluorescence of the SC and [E+D] of pig skin homogenates and adhesive tape compounds did not show any fluorescence intensity around this $\lambda(630 \mathrm{~nm})$ enabling PpIX assay in in vitro skin penetration studies. According to Drakaki et al. (2007), the pig skin spectrum (ex vivo and after defrosting) of its autofluorescence, after UV laser excitation at $\lambda=337.1 \mathrm{~nm}$, exhibits two maxima in the region of 390 and $440 \mathrm{~nm}$, which could be addressed to collagen (type, I and VI) fluorescence. Slight influence of oxy-hemoglobin absorption yields minima in fluorescence signals at 420, 545 and $575 \mathrm{~nm}$.

The fluorometric method described in the present study has the advantage of rapid and sensitive quantification of PpIX retained in the skin. Fluorescence intensity of the PS linearly correlated with concentrations in the range $0.005-0.5 \mu \mathrm{g} / \mathrm{mL}$ for DMSO and phosphate buffer $\mathrm{pH} 7.2$ $+\mathrm{CCP}$. The equation for a typical calibration curve, obtained by least squares linear regression, was $y=19,002 x$

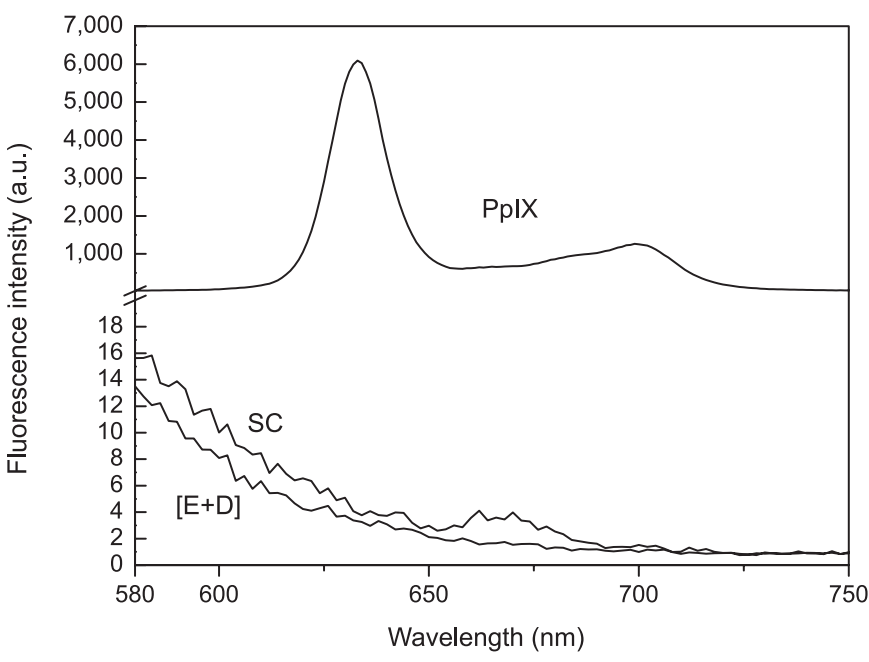

FIGURE 3 - Spectra referring to analyses of homogenates of $\mathrm{SC}$ and $[\mathrm{E}+\mathrm{D}]$ in comparison to the profile of a $5 \mu \mathrm{g} / \mathrm{mL}$ PpIX solution (DMSO) to evaluate the selectivity of the method. Specifications: Conditions: excitation $\lambda: 400 \mathrm{~nm}$; emission $\lambda_{\max }$ : $632 \mathrm{~nm}$; emission/excitation slits: $5 / 10 \mathrm{~nm}$.

$+171.6 ; \mathrm{r}=0.998(\mathrm{DMSO})$ and $\mathrm{y}=15,230 \mathrm{x}+144.3 ; \mathrm{r}=$ 0.998 (phosphate buffer pH 7.2 + CCP).

The within-day precision and accuracy of the assay were obtained by sequential analysis of PpIX solutions in DMSO at two distinct concentrations ( 0.04 and $0.2 \mu \mathrm{g} / \mathrm{mL}$ ). The within-day assay coefficients of variation (CV) for PpIX were lower than $2.0 \%$ and all between-day assay coefficients of variation were below $1.5 \%$ (Table I). The within-day and between-day assay accuracies were found to be 2.3 and $0.9 \%$ for $0.04 \mu \mathrm{g} / \mathrm{mL},-0.5$ and $-0.6 \%$ for $0.2 \mu \mathrm{g} / \mathrm{mL}$, respectively.

The within-day precision and accuracy of the assay were also obtained by sequential analysis of PpIX solu-

TABLE I - Analysis of the precision and accuracy of the fluorometric method for PpIX assay in DMSO

\begin{tabular}{|c|c|c|c|}
\hline Parameters & & Protoporphyrin IX & \\
\hline \multicolumn{4}{|l|}{ Precision (within-day) } \\
\hline Nominal standard concentration $(\mu \mathrm{g} / \mathrm{mL})$ & ${ }^{\mathrm{a}} 0.005$ & 0.04 & 0.2 \\
\hline $\mathrm{N}$ & 7 & 10 & 10 \\
\hline C.V. $(\%)$ & 6.9 & 1.5 & 0.9 \\
\hline \multicolumn{4}{|l|}{ Precision (between-day) } \\
\hline Nominal standard concentration $(\mu \mathrm{g} / \mathrm{mL})$ & ------ & 0.04 & 0.2 \\
\hline $\mathrm{N}$ & ------ & 5 & 5 \\
\hline C.V. $(\%)$ & ------ & 1.1 & 1.1 \\
\hline \multicolumn{4}{|l|}{ Accuracy } \\
\hline Within-day (\%) & -15.3 & 2.3 & -0.5 \\
\hline Between-day (\%) & ------ & 0.9 & -0.6 \\
\hline
\end{tabular}

$\mathrm{N}$ : number of determination; C.V., coefficient of variation; ${ }^{a}$ lower limit of quantification. 
TABLE II - Analysis of the precision and accuracy of the fluorometric method for PpIX assay in phosphate buffer pH 7.2 + CPC

\begin{tabular}{|c|c|c|c|}
\hline Parameters & & Protoporphyrin IX & \\
\hline \multicolumn{4}{|l|}{ Precision (within-day) } \\
\hline Nominal standard concentration $(\mu \mathrm{g} / \mathrm{mL})$ & ${ }^{\mathrm{a}} 0.005$ & 0.01 & 0.08 \\
\hline $\mathrm{N}$ & 7 & 10 & 10 \\
\hline C.V. $(\%)$ & 1.8 & 2.2 & 1.2 \\
\hline \multicolumn{4}{|l|}{ Precision (between-day) } \\
\hline Nominal standard concentration $(\mu \mathrm{g} / \mathrm{mL})$ & ------ & 0.01 & 0.08 \\
\hline $\mathrm{N}$ & ------ & 5 & 5 \\
\hline C.V. $(\%)$ & ------ & 3.5 & 1.3 \\
\hline \multicolumn{4}{|l|}{ Accuracy } \\
\hline Within-day (\%) & -1.9 & 0.01 & -0.13 \\
\hline Between-day (\%) & ------ & -0.9 & -0.002 \\
\hline
\end{tabular}

N: number of determination; C.V., coefficient of variation; ${ }^{\mathrm{a}}$ lower limit of quantification

tions in phosphate buffer $\mathrm{pH} 7.2+\mathrm{CCP}$ at two distinct concentrations $(0.01$ and $0.08 \mu \mathrm{g} / \mathrm{mL})$. The within-day assay coefficients of variation (CV) for PpIX were lower than $2.5 \%$ and all between-day assay coefficients of variation were below $4.0 \%$ (Table II). The within-day and between-day assay accuracies were found to be 0.01 and $-0.9 \%$ for $0.01 \mu \mathrm{g} / \mathrm{mL},-0.13$ and $-0.002 \%$ for $0.08 \mu \mathrm{g} / \mathrm{mL}$, respectively.

The detection limit of the assay was $0.002 \mu \mathrm{g} / \mathrm{mL}$ for DMSO and phosphate buffer pH 7.2 + CCP. The lowest concentration quantified by this method with acceptable precision and accuracy was $0.005 \mu \mathrm{g} / \mathrm{ml}$. This limit is adequate for the assessment of PpIX retained in the skin, since the PS is lipophilic, and is expected to be retained within the $\mathrm{SC}$ and $[\mathrm{E}+\mathrm{D}]$ rather than to permeate across the skin.

Table III shows the results of PpIX recovery, extracted from the skin samples ( $\mathrm{SC}$ and $[\mathrm{E}+\mathrm{D}])$. The recovery from $\mathrm{SC}$ and $[\mathrm{E}+\mathrm{D}]$ for the two concentrations tested $(0.5$ and $1.0 \mu \mathrm{g} / \mathrm{mL}$ ) were all above $90.0 \%$ of the spiked dose $(n=5)$. No studies describing the recovery of PpIX from skin samples were found in the literature. Studies focusing on the validation of topical drug recovery from porcine skin obtained variable results, ranging from an average of $82.0 \%$ (Ayub, Vianna-Soares, Ferreira, 2007), 97.0\% (Echevarria et al., 2003) and above $94.0 \%$ (Santoyo et al., 2002). According to Causon (1997), and compared with the recovery obtained by the studies described above, the method for PpIX extraction from skin layers in this paper resulted in a high PpIX recovery, demonstrating its suitability for application in cutaneous penetration studies.

The present fluorometric method developed for PpIX quantification in skin samples proved to be suitable for PpIX assay in different skin layers after in vitro
TABLE III - PpIX recovery from SC and [E+D] samples

\begin{tabular}{lcccc}
\hline Sample & \multicolumn{4}{c}{ Skin layers } \\
\cline { 2 - 5 } & \multicolumn{3}{c}{$\mathrm{SC}$} & \multicolumn{2}{c}{$[\mathrm{E}+\mathrm{D}]$} \\
\hline PpIX added $(\mu \mathrm{g} / \mathrm{mL})$ & 0.5 & 1.0 & 0.5 & 1.0 \\
PpIX extracted $(\mu \mathrm{g} / \mathrm{mL})$ & 0.47 & 0.90 & 0.48 & 0.95 \\
$\mathrm{~N}$ & 5 & 5 & 5 & 5 \\
Recovery $(\%)$ & 94.0 & 90.0 & 96.0 & 95.0 \\
\hline
\end{tabular}

$\mathrm{SC}=$ stratum corneum; $[\mathrm{E}+\mathrm{D}]=$ epidermis without stratum corneum + dermis; $\mathrm{N}=$ number of replicates.

penetration studies. At $12 \mathrm{~h}$ post-application, $0.13 \pm 0.01$ $\mu \mathrm{g} / \mathrm{cm}^{2}(\mathrm{n}=5)$ of PpIX was detected in the SC, and $0.016 \pm 0.002 \mu \mathrm{g} / \mathrm{cm}^{2}$ in the [E+D] (Figure 4). PpIX was not detected in the receptor samples (phosphate buffer $\mathrm{pH} 7.2+\mathrm{CCP}$ ) of the experiment probably because it is a high molecular weight lipophilic drug that does not

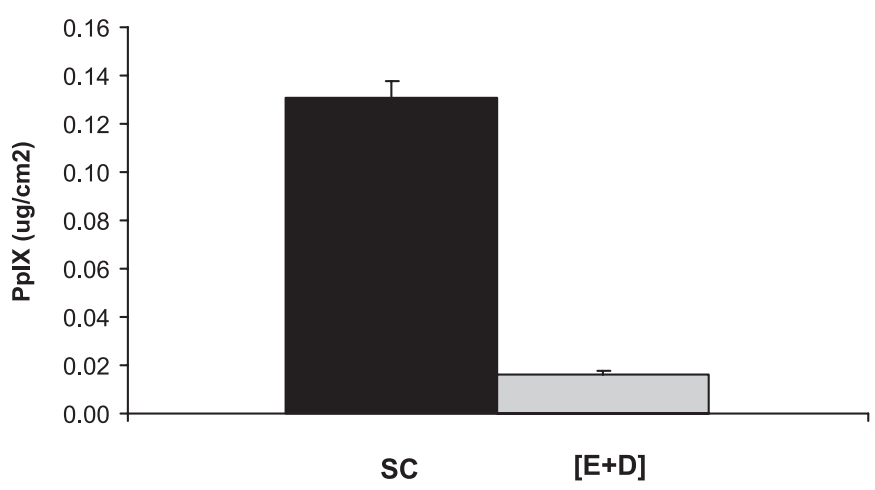

FIGURE 4 - PpIX in vitro penetration in the $\mathrm{SC}$ and [E+D] at 12 hours post-application of a photosensitizer solution in polyethylene glycol $(80 \mu \mathrm{g} / \mathrm{mL})$. Results presented are expressed as averages \pm SEM of five experiments. 
permeate the skin without a proper delivery system or the use of penetration enhancers.

\section{CONCLUSION}

The development of a fluorometric method for PpIX quantification in skin and permeation samples from in vitro penetration/permeation studies proved to be both accurate and precise. Small amounts of PpIX could be assayed and detected which is a very important feature for the screening of delivery systems. In addition, the method for skin recovery is relatively easy and rapid, and shows a high yield.

\section{ACKNOWLEDGEMENTS}

We gratefully acknowledge the financial support of the Fundação de Amparo à Pesquisa do Estado de São Paulo (FAPESP), Conselho Nacional de Desenvolvimento Científico e Tecnológico (CNPq) and the Coordenação de Aperfeiçoamento de Pessoal de Nível Superior (CAPES), Brazil.

\section{REFERENCES}

AYUB, A.C.; VIANNA-SOARES, C.D.; FERREIRA, L.A.M. Fluconazol method validation by RP-HPLC for determination in biological skin matrices. J. Chromatogr. Sci., v.45, p.286-290, 2007.

BODDÉ, H.E.; ROEMELÉ, P.E.; STAR, W.M. Quantification of topically delivered 5 -aminolevulinic acid by lontophoresis across ex vivo human stratum corneum. Photochem. Photobiol., v.75, p.418-423, 2002.

BRASIL. Agência Nacional de Vigilância Sanitária. Determina a publicação do "Guia para validação de métodos analíticos e bioanalíticos"; fica revogada a Resolução RE $n^{\circ} 475$, de 19 de março de 2002. Guia para validação de métodos analíticos e bioanalíticos. Diário Oficial da União, Brasília, DF, 02 jun. 2003. Seção 1, p. 56-59.

BROWN, S.B.; BROWN, E.A.; WALKER, I. The present and future role of photodynamic therapy in cancer treatment. Lancet. Oncol., v.5, p.497-508, 2004.

CASTANO, A.P.; DEMIDOVA, T.; HAMBLIN, M.R. Mechanisms in photodynamic therapy: party onephotosensitizers, photochemistry and cellular localization. Photodiagnosis Photodyn. Ther, v.1, p.279-293, 2004.
CAUSON, R. Validation of chromatographic methods in biomedical analysis. Viewpoint and discussion. $J$. Chromatogr. B, v.689, p.175-180, 1997.

DE ROSA, F.S.; MARCHETTI, J.M.; THOMAZINI, J.A.; TEDESCO, A.C.; BENTLEY, M.V.L.B. A vehicle for photodynamic therapy of skin cancer: influence of dimethylsulphoxide on 5-aminolevulinic acid in vitro cutaneous permeation and in vivo protoporphyrin IX accumulation determined by confocal microscopy. $J$. Control. Release, v.65, p.359-366, 2000.

DE ROSA, F.S.; TEDESCO, A.C.; LOPEZ, R.V.; PIERRE, M.B.R.; LANGE, N.; MARCHETTI, J.M.; ROTTA, J.C.G.; BENTLEY, M.V.L.B. In vitro skin permeation and retention of 5-aminolevulinic acid ester derivatives for photodynamic therapy. J. Control. Release, v.89, p.261-269, 2003.

DRAKAKI, E.; BORISOVA, E.; MAKROPOULOU, M.; AVRAMOV, L.; SERAFETINIDES, A.A.; ANGELOV, I. Laser induced autofluorescence studies of animal skin used in modeling of human cutaneous tissue spectroscopic measurements. Skin Res. Technol., v.13, p.350-359, 2007.

ECHEVARRÍA, L.; BLANCO-PRÍETO, M.J.; CAMPANERO, M.A.; SANTOYO, S.; YGARTUA, P. Development and validation of a liquid chromatographic method for in vitro mupirocin quantification in both skin layers and percutaneous penetration studies. J. Chromatog. B, v.796, p.233-241, 2003.

KENNEDY, J.C.; POTTIER, R.H.; PROSS, D.C. Photodynamic therapy with endogenous protoporphyrin IX: basic principles and present clinical experience. J. Photochem. Photobiol. B: Biol., v.6, p.143-148, 1990.

LOPEZ, R.F.V., BENTLEY, M.V.L.B., DELGADO-CHARRO, M.B., GUY, R.H. Iontophoretic delivery of 5- aminolevulinic acid (ALA): effect of pH. Pharm. Res., New York, v.18, p.311-315, 2001.

MATEO, R.; CASTELLS, G.; GREEN, A.J.; GODOY, C.; CRISTÒFOL, C.J. Determination of porphyrins and biliverdin in bile and excreta of birds by a single liquid chromatography-ultraviolet detection analysis. Chromatogr. B Analyt. Technol. Biomed. Life Sci., v.810, p.305-11, 2004.

MILLER, J.N. Some recent advances in fluorescence spectroscopy. Anal. Lett., v.39, p.851-862, 2006. 
OISHI, H.; NOMIYAMA, H.; NOMIYAMA, K.; TOMOKUNI, K. Fluorimetric HPLC determination of 5-aminolevulinic acid (5-ALA) in the plasma and urine of lead workers: biological indicators of lead exposure. J. Anal. Toxicol., v.20, p.106-110, 1996.

PIERRE, M.B.R.; RICCI, E.; TEDESCO, A.C.; BENTLEY, M.V.L.B. Oleic acid as optimizer of the skin delivery of 5-aminolevulinic acid in photodynamic therapy. Pharm. Res., v.23, p.360-366, 2006.

RICK, K.; SROKA, R.; STEPP, H.; KRIEGMAIR, M.; HUBER, R. M.; JACOB, K. BAUMGARTNER, R. Pharmacokinetics of 5-aminolevulinic acid-induced protoporphyrin IX in skin and blood. J. Photochem. Photobiol. B: Biol., v.40, p.313-319, 1997.

SANTANA, F.J.M.; CESARINO, E.J.; BONATO, P.S. New method for the chiral evaluation of mirtazapine in human plasma by liquid chromatography. J. Chromatogr. B, v.809, p.351-356, 2004.

SANTOYO, S.; DE JALÓN, E.G.; CAMPANERO, M.A.; YGARTUA, P. Determination of cidofovir in both skin layers and percutaneous penetration samples by HPLC. $J$. Pharm. Biomed. Anal., v.29, p.819-826, 2002.

SCOLARO, L.M.; CASTRICIANO, M.; ROMEO, A.; PATANÈ, S.; CEFALÌ, E.; ALLEGRINI. M. Aggregation Behavior of Protoporphyrin IX in Aqueous Solutions: Clear Evidence of Vesicle Formation. J. Phys. Chem. B, v.106, p.2453-2459, 2002.
SHAH, P.V.; MIDHA, K.K.; DIGHE, S.; MCGILVERAY, I.J.; SKELLY, J.P.; YACOBI, A.; LAYLOFF, T.; VISWANATHAN, C.T.; COOK, C.E.; MACDOWALL, R.D.; PITTMAN, K.A.; SPECTOR, S. Analytical methods validation: bioavailability, bioequivalence and pharmacokinetic studies. J. Pharm. Sci., v.81, p.209-314, 1992.

SIVASH, A.A.; MASINOVSK, Z.; LOZOVAYA, G.I. Surfactant micelles containing protoporphyrin IX as models of primitive photocatalytic systems: a spectral study. BioSystems, v.25, p.131-140, 1991.

SCHMOOK, F.P.; MEINGASSNER, J.G.; BILLICH A. Comparison of human skin or epidermis models with human and animal skin in in-vitro percutaneous absorption. Int. J. Pharm., Netherlands, v.215, p.51-56, 2001.

STELUTI, R.; DE ROSA, F.S.; COLLETT, J.; TEDESCO, A.C.; BENTLEY, M.V.L.B. Topical glycerol monooleate/ propylene glycol formulations enhance 5-aminolevulinic acid in vitro skin delivery and in vivo protophorphyrin IX accumulation in hairless mouse skin. Eur. J. Pharm. Biopharm., v.60, p.439-444, 2005.

ZEITOUNI, N.C.; OSEROFF, A.R.; SHIEH, S. Photodynamic Therapy for nonmelanoma skin cancers. Current review and update. Mol. Immunol., v.39, p.1133-1136, 2003.

Received for publication on $19^{\text {th }}$ October 2009. Accepted for publication on $15^{\text {th }}$ Mach 2010. 